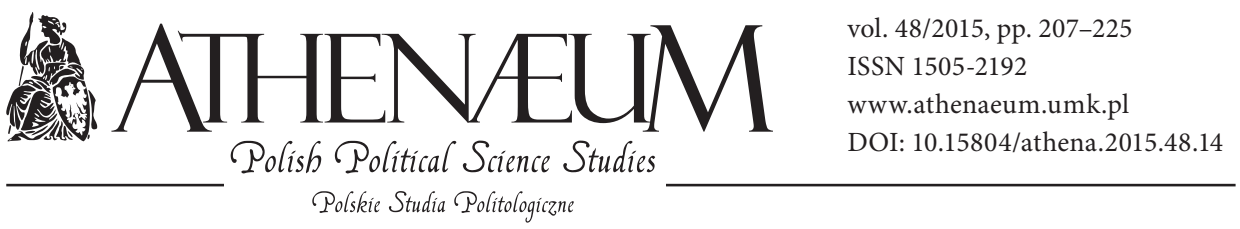

\title{
RATIONALIST THEORY OF INTERNATIONAL RELATIONS: THE CASE OF RELATIONS BETWEEN NORTH KOREA AND POLAND AFTER 1989
}

Nicolas Levi*

\begin{abstract}
This article focuses on relations between Poland and the Democratic People's Republic of Korea after 1989. Before 1989, bilateral relations between these countries were very close. As of now, the behavior of North Korea toward Poland is based on a rational behavior. The Polish foreign policy toward North Korea is within the EU framework, which supports an evolutionary change in character of the North Korean regime. Poland is involved in North Korea through different fields, especially such as the humanitarian one.
\end{abstract}

\section{- KEYWORDS -}

North Korea, DPRK, Poland, Rationalism Policy, asymmetry of relations

\section{INTRODUCTION}

The death of Kim Jong-il, the dictatorial leader of North Korea (North Korea is also called the Democratic People's Republic of Korea [DPRK]), on December $17^{\text {th }}, 2011$, leaves a number of questions unanswered for the future of North Korea. This event may lead to changes within the North Korean global strategy and its foreign policy. Back in the past, the fall of the communism already changed the foreign policy of the DPRK.

* Polish Academy of Sciences, Institute of Mediterranean and Oriental Cultures. 
In 1989, Poland ${ }^{1}$ lost its status as a communist friend and its privileged position in contacts with North Korea. However, despite the change from communism to capitalism in Poland in 1989 and the establishment of relations with South Korea, relations between Poland and the DPRK remain at a fair level.

Poland still continue to support international efforts to promote peace and stability on the Korean Peninsula, in particular through the Six Party Talks process, set up in 2003 to address international concerns over the nuclear activities of North Korea (Radio Poland: 2012). Polish authorities tried in the past to conduct regular political dialogues with North Korea. Since the 1950s, Poland has been also providing humanitarian assistance to North Korea. This paper aims at preparing a strategy concerning the future of relations between Poland and North Korea based on the fact that the DPRK is an actor of International Relations which maximize choices based on transitive preferences being a rationalist state. It is a decisive topic, which remains important, especially for the future of the North Korean nation which is at least partially dependant of the foreign assistance, including the Polish one. The paper aims also to prove the following issues: the DPRK is an actor of International Relations which maximizes choices based on transitive preferences. There are no anomalies in North Korea's strategic move in the case of its relations with Poland as the DPRK is a rational actor.

Following this introduction, this paper is organized into six substantive chapters. The first section begins with a discussion related to the methodology of this article. The second section is related to the theory of rationalism in international relations. The next chapter examines how social changes in Poland which took place in the $1980^{\text {s }}$ affected the diplomatic relations between both countries. The fourth and fifth chapters discuss economic and cultural relations between both countries. The final chapter is dedicated to the prospects for the relations between both countries and how to rethink the foreign policy of Poland towards North Korea in order to formulate a more appropriate policy which would bring advantages to both parties. Moreover, the paper is based upon Polish, South Korean, and North Korean sources. This article looks into the perspectives mentioned above, however due to the quite different topics mentioned it cannot be an exhaustive guide to North Korean-Polish relations.

1 The Polish People's Republic was the official name of Poland between 1952 and 1989. The country was renamed as the Republic of Poland in 1989. 


\section{METHODOLOGY}

This article uses a combination of quantitative and qualitative methods in order to analyze the mentioned topic. The whole is done in order to develop important observations and draw conclusions. On the other side, based on statistical data provided by the Polish Ministry of Economy, some elements are quantifiable and may affect the analysis of the considered policy. The paper aims at interpreting the policy of the two countries with a focus on diplomatic, economic, and cultural issues. The collection of data was also affected by the fact that the Polish Ministry of Foreign Affairs is not disclosing its diplomatic information related to the last 25 years. Therefore some of the sources are based on interviews and Internet data. This article supports the hypothesis and theoretical conclusion that the DPRK national interest was prevalent in the establishment of relations with Poland and that therefore there is an asymmetry in the quality of relations between both countries.

\section{THEORETICAL BACKGROUND}

In international relations, scholars seek to explain how to interpret the behavior of nations and states (wars, alliances...). Any explanations are provided through theory. Within the last decades, new approaches dedicated to the theory of International Relations appeared. One of them is the Rational Theory of International Relations. Rational choice theory is rooted in the assumption of instrumental rationality. Rationalism is a behavior that can be optimally adapted to the situation. A rational actor is one who, when confronted with "two alternatives which give rise to outcomes, will choose the one which yields the more preferred outcome" (Luce, Raiffa 1989: 50). Kahneman and Tversky, two Israeli-American researchers, developed a prospect theory to gather these patterns into a theory of choice. Two phases are distinguished. The first one is the reference point, the options available and potential outcomes. In the present case, the editing phase will be the post-Korean War period when North Korea used as much as it could opportunities provided by the Polish People's Republic. It is also important to underline that the outcomes depend of preferences, which are determined by each entity or state. The American political scientist Kenneth Waltz focuses on three sorts of factors related to security strategies: motivation of a state, its capabilities, and information it collects on the capacities and intentions of others. 
The rationalist theory deduces the circumstances under which states will seek to cooperate or compete. It is a strategic choice theory for a state (in the present case, North Korea) facing an international environment that presents constraints and opportunities (Glaser 2010: 1). The second phase is the evaluation phase, which is described within a Utility model (applied in microeconomics) which can be associated to the behavior of North Korea. It will assume that the state will make rational decisions to maximize its gains within its relations with Poland. The potential gain for North Korea will be an inflow of foreign currency through different channels presented below.

\section{RELATIONS BETWEEN POLAND AND NORTH KOREA BETWEEN 1989 AND 2015}

As an introduction, I would like to summarize the relations between both countries between 1948 and 1989 (Levi 2009: 345-363). Poland recognized the DPRK on the October $16^{\text {th }}, 1948$, and was one of the first states which diplomatically recognized the DPRK. The DPRK was the country which represented the Korean Peninsula in the communist world for the next 41 years. Due to historical reasons, during the period of the Cold War, Poland maintained limited but good relations with the DPRK. It is interesting to remark that Juliusz Burgin, the first Polish ambassador to the DPRK, was appointed only on December $24^{\text {th }}, 1950$.

Given the fact that Korean War, which occurred between 1950 and 1953, exchanges between both countries were limited to a marginal economical cooperation and mostly to the support of Poland to the DPRK related to the reconstruction of the DPRK. Poland provided a financial support (transport of medicine and food) and assisted the DPRK by taking about 1200 orphans and students who arrived in late 1952 (Krysowata 2004: 100-102). On June $8^{\text {th }}, 1953$, Poland became a member of the Neutral Nations Repatriation Commission (NNRC), which was supposed to oversee the repatriation process of prisoners of war from the Korean War. This organ was also composed by the Czechoslovakia, Sweden, and Switzerland.

Between 1953 and 1989, the cooperation between both countries was especially concentrated on cultural exchanges and some minor trade. According to Mieczysław Dedo², due to similarities (two wars which destroyed two capitals:

\footnotetext{
2 Interview with Mieczysław Dedo. The interview was held on April $4^{\text {th }}, 2010$. Mieczysław Dedo
} 
Warsaw and Pyongyang) and common ideologies, many Polish songs and movies were presented in the DPRK and many North Korean movies were also available in Poland (Krysowata 2004: 98-122). As mentioned above, North Korea needed Poland rather than Poland needed North Korea due to its national and economical interests. The first stage of the relationship, from 1949 until 1953, could be also characterized as a period during which there were intensified efforts of Poland toward the reconstruction of the DPRK. The second phase of the relations, from 1953 to 1989 , can be characterized as a period where the DPRK look for a financial support from countries belonging to the Warsaw Pact. This was a period of turbulences and confusion where Poland was not in position of challenging the Soviet Union as did the DPRK. This was due to the fact that Poland was a member of the Warsaw Pact at the difference of the DPRK, which did not join this organization.

The state of relations between both countries changed in the late $1980^{\text {s }}$ for internal and external reasons. First let's mention the internal reasons: when the dominance of the Polish United Workers' Party has been eroded and in 1989 Solidarnosc had triumphed in Poland's first partially free parliamentary elections since 1945, the DPRK showed its objections. Later Lech Wałęsa, a noncommunist official, won the presidency in 1990. On an external basis, another fact which depreciates the quality of relations between Poland and the DPRK was the opening of official ties between Poland and South Korea on November $1^{\text {st }}, 1989$ (Szczudlik-Tatar, Mejssner 2014: 2). The relations between Poland and North Korea were strongly affected by this fact as North Korea considered this act as a betrayal. 6 years later, in 1995, Polish soldiers were withdrawn from the Neutral Nations Supervisory Commission (NNSC). Within the next days, the Polish ambassador Ryszard Baturo was recalled by the Polish Ministry of Foreign Affairs after being 4 years in Pyongyang. North Korean authorities also recalled its diplomats based in Warsaw, as well as other North Koreans based in Poland such as North Korean workers, students, technical specialists, and sportsmen among others ${ }^{3}$. A major part of the small community of Poles based in the DPRK

is a former Polish diplomat who was twice the Polish representative to the DPRK. Mieczysław Dedo passed away in December 2014.

${ }^{3}$ For example, until the end of the 1990s, a dozen of North Koreans were studying at the Gdynia Maritime University. Due to structural changes which occurred in Poland, all of them (including two North Korean agents who were responsible for their journey in Gdynia) left Poland from one day to the next. The reason for their departure mentioned by the DPRK embassy in Poland was their participation in military exercises in North Korea. They never came back to Poland. Nevertheless, on 
was also forced to leave this country. Nevertheless it should be noted that the Polish journalist Krzysztof Darewicz was the only one Western reporter who was able to assist to the funerals of Kim Il-sung in 1994 (The New York Times 1994). It may be a symbol of the double ecke policy of the DPRK.

These relations changed after 1997. After some consultations between both countries, Pak Sang-am, a new DPRK ambassador to Poland, was appointed on July $19^{\text {th }}, 1997$. Pak Sang-am represented also the DPRK interest in Hungary (Iroda 1998). In 1998, he was removed from his position and sent back to North Korea. The former North Korean ambassador was replaced by Kim Pyong-il (Levi 2010: 33-49), a step-brother of Kim Jong-il, who was considered in the $1970^{\text {s }}$ as an enemy of the North Korean leader (Levi 2010: 40-47). Kim Pyong-il being sent to Poland was considered as a threat for the regime. He was nominated as one of the youngest North Korean diplomats of the DPRK diplomatic corps.

Age of selected DPRK diplomats

\begin{tabular}{|l|l|l|c|c|c|}
\hline Identity & $\begin{array}{l}\text { Year of } \\
\text { Birth }\end{array}$ & Country of Accreditation & $\begin{array}{c}\text { Year of } \\
\text { Accredita- } \\
\text { tion }\end{array}$ & $\begin{array}{c}\text { Age at the } \\
\text { Accredita- } \\
\text { tion }\end{array}$ & $\begin{array}{c}\text { Time Spent } \\
\text { as an } \\
\text { Ambassador }\end{array}$ \\
\hline Kim Pyong- il & 1954 & Hungary & 1988 & 34 & 2 months \\
\hline Kim Pyong-il & 1954 & $\begin{array}{l}\text { Poland } \\
\text { the } 4^{\text {th }} \text { country } \\
\text { where he was based) }\end{array}$ & 1998 & 44 & 16 years \\
\hline $\begin{array}{l}\text { Kim } \\
\text { Kwang-sop }\end{array}$ & 1952 & $\begin{array}{l}\text { Czechoslovak Socialist Republic } \\
\text { (until 1990) and Czechoslovakia } \\
\text { (until 1993) }\end{array}$ & 1985 & 33 & 8 years \\
\hline $\begin{array}{l}\text { Kim } \\
\text { Kwang-sop }\end{array}$ & 1952 & $\begin{array}{l}\text { Austria (the 2nd where he was } \\
\text { based) }\end{array}$ & 1993 & 41 & 21 years \\
\hline Jon Hui-jong & 1930 & Cambodia & 1968 & 38 & 5 years \\
\hline Kim Jae-gyong & 1934 & Sweden & 1974 & 40 & 2 years \\
\hline Choe Su-il & 1950 & Pakistan & 1991 & 41 & 4 years \\
\hline Paek Nam-sun & 1929 & Poland & 1974 & 45 & 5 years \\
\hline Kim Hung-rim & 1947 & Sweden & 1995 & 48 & 5 years \\
\hline
\end{tabular}

tMay $13^{\text {th }}, 1989$ (before the fall of the Berlin Wall), a Taekwondo match between the team of Poland and the DPRK took place in Koszalin. A few weeks later, the junior Polish team went to Pyongyang for the $13^{\text {th }}$ International Festival of the Youth and Students, which was held in the capital of North Korea. 


\begin{tabular}{|l|l|l|c|c|c|}
\hline Identity & $\begin{array}{l}\text { Year of } \\
\text { Birth }\end{array}$ & Country of Accreditation & $\begin{array}{c}\text { Year of } \\
\text { Accredita- } \\
\text { tion }\end{array}$ & $\begin{array}{c}\text { Age at the } \\
\text { Accredita- } \\
\text { tion }\end{array}$ & $\begin{array}{c}\text { Time Spent } \\
\text { as an } \\
\text { Ambassador }\end{array}$ \\
\hline Pak Ui-chun & 1932 & Algeria & 1980 & 48 & 7 years \\
\hline Ri Won-guk & 1931 & Zimbabwe & 1980 & 49 & 5 years \\
\hline Paek Yong-ho & 1945 & Morocco & 1997 & 52 & 3 years \\
\hline Kim Guk-hun & 1919 & Cuba & 1972 & 53 & 5 years \\
\hline
\end{tabular}

Document prepared by the author based on data collected from the various issues of "Vantage Point" (a South Korean research journal focused on North Korean matters)

On the Polish side, a Polish ambassador was one more time sent to Pyongyang in 2001, and Poland became one of the seven European countries with an embassy in the DPRK. Poland was then represented by Wojciech Kaluza. Between 2005 and 2014, each of Polish ambassadors who served in Pyongyang had a military background (many are retired officers or senior non-commissioned officers). Some of them told the author of this article that North Korean authorities pay a high esteem to foreign military officials. The last ambassador of Poland to North Korea was General Edward Pietrzyk, who previously served as the Polish ambassador in Iraq (2007-2010). Before him, Roman Iwaszkiewicz served and was a General of the Polish Army. Edward Pietrzyk was replaced by Krzysztof Ciebień in 2014, who is the first Polish civil ambassador since 2005.

Concerning diplomatic visits, in 2001, Radosław Sikorski, the deputy minister of the Ministry of Foreign Affairs of the Republic of Poland came to the DPRK for political consultations as a part of the strategy on relations between the DPRK and the EU (Seliger 2010: 180). These consultations were repeated in 2004 and 2007. On the other side, the DPRK delegation was sent to Poland in 2008 and between the $15^{\text {th }}$ and the $17^{\text {th }}$ October 2008, the Deputy Minister for Foreign Affairs Ryszard Schnepf was in North Korea for the celebration of the 60 years of relations between both countries. 3 years later, the DPRK deputy minister for foreign affairs, Kung Sok-ung, was in Poland on September $13^{\text {th }}, 2011$, in Warsaw. Between the $17^{\text {th }}$ and the $20^{\text {th }}$ September 2013, Filip Grzegorzewski, the director of the Asian department of the Ministry of Foreign Affairs of Poland, paid an official visit to the DPRK.

In 2003, North Korea withdrew from the Treaty of Non-Proliferation of Nuclear Weapons. No meetings between representatives of Poland and North Korea took place until 2006. It is also important to mention that in spite of the limited "visible" cooperation between both countries, some hidden elements 
remain unavailable to the public. North Korea is also trying to approach the Poles on the issue of establishing relations with capitalist countries, especially with Japan and the US. Moreover, some of the meetings related to the nuclear program of the DPRK were held in Warsaw. This diplomatic channel in Warsaw is one of the main reasons of the maintaining of relations between both countries in spite of the limited cooperation as we will see in the next point of this article. The role of the DPRK embassy in Warsaw can be compared (within its limits) to the role of the Chinese embassy in Warsaw, which secretly and partially organized the visit of Richard Nixon in Beijing in 1971 (Komine, 2008: 116).

Polish ambassadors to DPRK

\begin{tabular}{|l|l|}
\hline Mieczysław Dedo & $1986-1990$ \\
\hline Ryszard Baturo & $1991-1995$ \\
\hline Mieczysław Dedo (chargé d’affaires) & $1996-2001$ \\
\hline Wojciech Kałuza & September 2001-December 2005 \\
\hline Roman Iwaszkiewicz & December 2005-October 2009 \\
\hline Edward Pietrzyk & November 2009-December 2014 \\
\hline Krzysztof Ciebień & December 2014- ... \\
\hline
\end{tabular}

DPRK ambassadors to Poland

\begin{tabular}{|l|l|}
\hline No ambassadors & $1989-1998$ \\
\hline Pak Sang-am & 1997 \\
\hline Kim Pyong-il & $1998-2015$ \\
\hline Ri Gun & $2015-\ldots$ \\
\hline
\end{tabular}

Agreements and Protocols signed between Poland and the DPRK since 1989:

\begin{tabular}{|l|c|}
\hline Type of Agreements & $\begin{array}{c}\text { Signature } \\
\text { Date }\end{array}$ \\
\hline $\begin{array}{l}\text { Trade and Payment Agreement between the Government of the Republic of Poland and } \\
\text { the DPRK. }\end{array}$ & May $12^{\text {th }}, 1992$ \\
\hline $\begin{array}{l}\text { Protocol between the Government of the Republic of Poland and the DPRK on regula- } \\
\text { tion of mutual obligations in clearing rubles in payment relations due to the alteration of } \\
\text { the convertible currency payments from 1 January } 1991\end{array}$ & May $12^{\text {th }}, 1992$ \\
\hline
\end{tabular}




\begin{tabular}{|l|c|}
\hline Type of Agreements & $\begin{array}{c}\text { Signature } \\
\text { Date }\end{array}$ \\
\hline $\begin{array}{l}\text { Agreement between the Government of the Republic of Poland and the DPRK on } \\
\text { co-operation of fisheries. }\end{array}$ & $\begin{array}{c}\text { October 2 } \\
\text { nd } \\
1997\end{array}$ \\
\hline $\begin{array}{l}\text { Protocol between the Government of the Republic of Poland and the DPRK on validity } \\
\text { of bilateral international agreements in relations between the Republic of Poland and } \\
\text { the Democratic People's Republic of Korea }\end{array}$ & $\begin{array}{c}\text { February } 1^{\text {st }}, \\
2007\end{array}$ \\
\hline $\begin{array}{l}\text { Protocol between the Government of the Republic of Poland and the DPRK on validity } \\
\text { of bilateral international agreements in relations between the Republic of Poland and } \\
\text { the Democratic People's Republic of Korea }\end{array}$ & June $15^{\text {th }}, 2015$ \\
\hline
\end{tabular}

\section{COMMERCIAL COOPERATION BETWEEN POLAND AND NORTH KOREA}

Both countries seem to have a special relationship at least when it comes to business. Indeed, the first and oldest foreign joint venture company in North Korea is Polish. It is a shipping company with offices in North Korea and Poland. One of 12 founders of the European Business Association (EBA) in Pyongyang was the Polish CEO of the company in Pyongyang. The foundation ceremony of the EBA was also attended by a visiting Polish business delegation headed by the Vice Minister of the Polish Ministry of Transportation. Additionally, according to Felix Abt, a Swiss businessman who was based in Pyongyang in the 2000s, Polish people were those who contacted him on seeking advice on how to do business in North Korea in the last 12 years more than by any other European nationality ${ }^{4}$.

In a nutshell, the commercial cooperation between Poland and North Korea is highly limited to some minor activities, as we will see below. Poland is exporting meat, industrial machines and tools, clothing and medical supplies. Concerning North Korea, this country is exporting mainly raw materials and spare parts to Poland. The DPRK is also exporting to Poland some products which are produced by South Korean companies based in the Kaesong Industrial Complex.

4 Interview with Felix Abt, a Swisss businessman who was based in North Korea for over 10 years between 1992 and 2002. The interview was held on December $18^{\text {th }}, 2014$. 
Starting from the mid-2000s, many North Koreans were also dispatched on rural areas of Poland, where they were learning agricultural techniques (Wojniak: 2006). Polish authorities are also donating farm machines to North Korean cooperatives (KCNA: 2008). The first discussions related to this topic were performed via a meeting between a North Korean delegation led by Kil Sang-bong, the vice-chairman of the Central Committee of Agricultural Workers of Korea, and the Polish Ministry of Agriculture in 2005 (KCNA: 2005).

Mieczysław Dedo, a former Polish Ambassador to North Korea, has always described his visits with the North Korean leadership as "nice", but emphasizes the difficult economic situation of the country. These difficulties coupled to the economical model of the DPRK which limits the exchange between the DPRK and foreign countries. As of 2004, the value of the exchanges between both countries was about $10 \mathrm{mln}$ of USD. Concerning economic ties, they were always very limited. The current cooperation is limited to the activities realized by Chopol, a North Korean-Polish maritime shipping company which is still functioning. It is also worth to note that some Polish companies participated to international trade fair which took place in Pyongyang (Bobber 2011: 29). Edward Pietrzyk, the former Polish ambassador to the DPRK between 2009 and 2014, has also been seen in the past at some Fair Trade involving business in North Korea and at the main table of receptions between the diplomatic corps in Pyongyang and North Korean businessmen (Yang 2012).

Data regarding commercial exchanges for the years between 2010 and 2013 are presented below.

Polish Trade with North Korea (in mln of USD)

\begin{tabular}{|l|c|c|c|}
\hline Year & $\begin{array}{c}\text { Polish Export } \\
\text { to the DPRK }\end{array}$ & $\begin{array}{c}\text { DPRK Import } \\
\text { to Poland }\end{array}$ & Trade Balance \\
\hline 2010 & 0,8 & 16,9 & $-16,1$ \\
\hline 2011 & 1,4 & 10,9 & $-9,6$ \\
\hline 2012 & 0,2 & 5,02 & $-4,8$ \\
\hline 2013 & 0,5 & 7,5 & -7 \\
\hline
\end{tabular}

Source: Polish Ministry of Foreign Affairs

North Korea has also an outstanding debt owed to Poland since the 1970s, which is still unregulated. As of 2011, the DPRK owed to Poland a debt estimated at about 4.3 millions of USD (Bobber 2011: 29). From the Polish point of view, 
during the Cold War it was seen as necessary to support a fraternal regime, and the financial returns were considered as unimportant. With increasing demands from the DPRK side for further support for post-War reconstruction and development of North Korea, the question of payment arose and there was some tension which particularly emerged after the fall of the Berlin Wall and the disintegration of the Soviet Bloc (Yang: 2012). If North Korea is going to repay its debt, which is rather not possible in the foreseeable future, the trust toward this country may increase as its transparency. Reschedule the debt in exchange of reforms maybe also a solution to this financial issue.

\section{DISPUTE BETWEEN POLAND AND NORTH KOREA}

There are many disputes which are jeopardizing an amelioration of relations between both countries. One of them is related to the renting of parts of the DPRK embassy in Warsaw to various companies (Ciszewski Public Relations, 4Fun Media, The Venue among others) and Non-Governmental Organizations (for example the NGO "Czas na Muzykę") since 2008.

Since the beginning of the 2000s, North Korea has also dispatched hundreds of construction and agricultural workers to Poland, sending them to sites in several cities mainly in the northwest, south-east of the country, and in the suburbs of Warsaw. The total number of North Koreans working in Poland is currently more than five hundred. They live under the strict control of Polishspeaking North Korean supervisors (Levi 2010). As of 2014, they are living in different parts of Poland (Gdansk, Szczecin, suburbs of Krosno, Piotrowice among others). The North Koreans work for more than 10 hours a day. Their wages are deposited into a communal bank account controlled by the North Korean government in dollars or in zlotys, the Polish currency. More than the half their wages are deducted for the cost of food or so-called voluntary contributions. There are many such similar cases. As far back as 2006, the Polish newspaper "Gazeta Wyborcza" covered the story of North Koreans working as welders in the Gdansk Shipyard, which was suffering a staffing crisis. They were supposed to be paid 600 Euros a month; however, after deductions, they were receiving only 15 Euros. The problem in Poland, as for many of the countries where the North Koreans are to be found, is that there are no legal restrictions regarding the employment of North Koreans, so as long as the North Koreans have work permits there is nothing more their host government can or need do. 
The only possible legal basis for contesting the situation, for some of the workers at least, is Article 1 of an "EU Council Framework Decision of 19 July 2002 on combating trafficking in human beings". These North Koreans are included in the utility model mentioned at the beginning of the article. The aim for North Koreans is to maximize their income in foreign currencies. The method is the utilization of its workforce abroad, which, in exchange of foreign currencies, is realizing a concrete job.

Moreover, in 2005, the American authorities accused North Korea of manufacturing high-quality counterfeit 100 USD bill notes. Many of these notes were manufactured under auspices of the government of North Korea and were exported through North Korean diplomatic representations. According to American officials, one of these diplomatic representations might be the Polish outpost, which was used to provide notes to potential customers, including Sean Garland, the leader of the Marxist-Leninist Worker's Party, an arm of the Official Irish Republican Army, who regularly visited the North Korean embassies in Russia and Poland.

In May 2011, three North Koreans were arrested in Ukraine for trying to smuggle 20,000 packs of cigarettes into Poland. There were supposed to be working at the North Korean embassy in Poland. All of them were protected by their diplomatic immunity.

In 2013, Andrzej Kompa, the owner of Kompa Investment Co., lent more than 2 million USD to the North Korean government through the embassy to carry out work on the building in 2005. The North Korean government never reimbursed the Polish businessman.

In spite of these (not always confirmed) misunderstandings between North Korean and Polish authorities, and because of the minor consequences of these facts, economic relations between both countries have a real potential. In the current economic situation, Polish companies face many challenges, they must find new markets and North Korea is an interesting option because its local tariffs are lower than in China and the North Korean market of wealthy people is increasing. Therefore, due to historical and constructive relationships and on its experience, Poland should be a pioneer in terms of prosperous relations with North Korea. Invest in North Korea should no more be considered as a risky adventure or a bet, it should be envisaged as a kind of new frontier of business development (Roussin, Ducruet 2010: 265) for Polish companies. However, major obstacles include North Korea’s aggression behavior, its nuclear activities, some issues dealing with human rights record, and its illegal activities. 
Nevertheless, we can hope that with the death of Kim Jong-il and the profound economic changes through the open policy of Kim Jong-un (You Ji 2014: 106), the new leader of North Korea, we will see a new path concerning the relations between the DPRK and foreign countries and I personally believe, these relations may result on a bright future for the North Korean nation. We also find that economic relations between Poland and the DPRK have a substantially greater non-commercial component through the cultural cooperation.

\section{THE HUMANITARIAN AND CULTURAL COOPERATION BETWEEN POLAND AND THE DPRK}

With the activation of the Lisbon Treaty, signed by the EU member states on December $13^{\text {th }}, 2007$, the EU became apolitical unit with a defined strategy concerning North Korea. From this year, Poland has had to follow the EU directives regarding North Korea in some subjects, such as the nuclear crisis or human rights. However, there are some fields where Poland can act alone. This field covers the some of the interactions between both countries. In spite of the nature of the North Korean regime, a win-win game can be imagined through humanitarian and cultural cooperation.

Cultural diplomacy can be defined as follow. It is a set of actions which are based on the exchange of ideas, values, and traditions, whether to strengthen socio-cultural cooperation or promote national interests. Cultural diplomacy can be practiced by either the public sector, private sector, or the civil society.

First, Poland is supporting North Korea on humanitarian issues (including financial support and dealings with humanitarian rights). Regarding humanitarian rights, the Polish Embassy in Pyongyang is regularly informing the DPRK government on its position on human rights. For example, in May 2008, when a DPRK Deputy Foreign Minister visited Poland for consultations, Krzysztof Ciebień, a former Polish consul to China and the current Polish ambassador to the DPRK, said that DPRK diplomats were open in its criticism of the human rights situation in North Korea. Regarding humanitarian assistance, Polish humanitarian organizations, such as Polska Akcja Humanitarna (PAH), are present over North Korea. It is one of the few aid agencies present in North Korea. The considered support is, however, partially monitored by North Korean entities and the previous mentioned PAH. This paper must also evocate the role of Joanna Hosaniak, a Polish woman committed to Human Rights in North 
Korea. She is a senior programs officer with the activist group Citizens' Alliance for North Korean Human Rights.

The humanitarian support has a historical background. Since 1952, Poland has been assisting the DPRK in some efforts to grow its own capabilities of food production. Polish organizations sent large quantities of rural technologies and fertilizers and trained North Koreans (Levi 2010: 347-355).

Besides, Poland is also accepting North Korean defectors, some of them are living in different parts of the country. Some North Korean students who were based in Poland in the 1980' defected in 1989. Some others are living in Poland. However, one of the problem lies on the fact that some of the North Korean defectors do not speak Polish and therefore can find only physical jobs (Levi 2012). The South Korean community in Poland is also not big enough to provide full-time jobs to potential North Koreans defectors.

The DPRK foreign policy may change with the arrival of a new leader such as Kim Jong-un. This leader is realizing a policy which is different from the one which was realized by his father. The traditional North Korean planned and militarian economy is being emulated by more reform-oriented process. Therefore we can imagine that the North Korean leadership will promote some economical changes which may open North Korea and change the nature of the regime. This lack of economic expertise due to a closing to the knowledge transfer for sixty years as of now combined to long relations between both countries may have an impact on the nature of relations between the DPRK and Poland. Furthermore, since 2002, North Korean bureaucrats have been authorized to receive training from abroad in some economic-related subjects (Beck, Reader 2010: 45). Then what could be the role of Poland in such a configuration? In addition to NGO activities, some Polish universities may opt for an expanding of their engagements with the DPRK. We can also imagine that Polish economists may educate the future leadership of North Korea. Some Polish specialists (such as Grzegorz Kolodko, a Polish professor of economics and a former Minister of Finance between 2002 and 2003, who went to North Korea for education project purposes, or Jacek Mironski, who was an active participant to the conference entitled "Economic Reform and the Development of Economic Relations between the EU and the DPRK", which took place in Pyongyang in October 2005) may participate in the elaboration of a new DPRK leadership. These specialists may be motivated for educating about entrepreneurship, free markets and the linkages between economic and societal liberalization at the relatively open-minded Pyongyang University of Sciences and Technology, or through the Swiss MBA Programme 
(Young-hur 2010: 45). The aim of Poland would be to provide some knowledge to North Korean specialists in order to enable them to change their country. In exchange we can imagine that North Korea may give Poland access to its raw materials (for instance, giving some long-terms concessions).

In terms of culture, the situation is different. Poland is participating in significant number of cultural events in the DPRK and North Koreans are also visible through contests in Poland. Polish movies companies participated to the $17^{\text {th }}$ International Festival of Cinema of Pyongyang. In this festival, Poland has won many awards, including the prize for Best Film in the year 2000 for the film $U$ Pana Boga za piecem. Some Polish producing companies participated to these event (Chronos and Poltel).

Meanwhile, many North Koreans were educated at the famous Leon Schiller National Higher School of Film, Television and Theatre in Łódź. Some of them participated to the conceptions of Polish movies. Rex and Przygody Kapitana Clippera (The Adventures of Captain Clipper), both Polish animated series, were prepared by a certain number of North Koreans who were educated in Poland (including Kim Un-chun, Chon Song-chol, Kim Dog-jong, Kim Kwan-son, Kwon Jon-kil, Pak Gwang-hyon - decorator; all of them worked on the preparation of the Polish cartoon Rex). Many North Korean companies are also still subcontracted to work for European producers of children films (Park 2010: 287).

There is also a DPRK-Poland Friendship Association with branches all over Poland. Members of this association are defending the North Korean political model. They are also translating into Polish the propaganda sent from Pyongyang. People who belong to this association are sometimes considered as "useful idiots".

At the spring festival (which gathers artists from all over the world) of Pyongyang, Poland is also sending some delegations (in 2002 from the Frederic Chopin University of Music of Warsaw and from the University of Music of Wrocław in 2003). During the $25^{\text {th }}$ Spring Friendship Festival in April 2007 the Polish singer Danuta Stankiewicz won the contest. In 2012, Poland was represented by Joanna Ławrynowicz who participated to the previous mentioned festival between the $10^{\text {th }}$ and the $18^{\text {th }}$ April 2012.

On the other side, Poland is promoting young North Korean scholars who want to get an education in Poland. The North Korean students Choe Janghung and Ri Yu-jong won recently the Chopin Prize (KCNA 2012). According to Eukasz Graban, a Polish official responsible for Korean affairs at the Polish 
Ministry of Foreign Affairs, a soccer match between Poland and the DPRK is also planned in a near future ${ }^{5}$.

Regarding educational exchanges, some projects are realized between both countries. For example, a Polish-North Korean dictionary of 530 pages was published on 7500 copies in 2012. This dictionary was jointly prepared by Polish koreanists (Małgorzata Terlecka, Tadeusz Korsak, and Magdalena Hornung) and North Korean scholars (Kim Song-il, Kim Min-chol, and Kim Jong-ho). This project was supported by the Polish Humanitarian Organization (Polska Akcja Humanitarna) and the Polish Ministry of Foreign Affairs. North Korean scholars who were involved in the projects were students from the Polish Faculty of the University of Foreign Languages of Pyongyang, which was established in 2005. The Polish Ministry of Foreign Affairs sponsored computers for the Faculty of Polish Language at the Foreign Languages University in Pyongyang. Jo Song-mu (Jo Song-mu is a former North Korean orphan who was educated in Poland in the 1950s during his high school and university), the head of this faculty, received a Polish award as an expert on the Polish language in 2010 (Wojnarowski 2010). Some North Koreans were also granted facilities to study the Polish language at the Warsaw Centre of Polish Language and Culture for Foreigners. North Korean is also sometimes exhibited in Poland. Between the $2^{\text {nd }}$ and the $6^{\text {th }}$ September 2008, there was an exhibition in Warsaw which was dedicated to the $60^{\text {th }}$ anniversary of the opening of diplomatic relations between Poland and the DPRK. Other exhibitions were held mainly in Gdansk, where there is a major University Center of Asian Studies. The last one was held in September 2014 (KFA Poland: 2014).

\section{CONCLUSION}

Given the uncertainties surrounding personnel (nominations at the head of North Korea) and events (a potential collapse of the North Korean system) that may influence prospects for DPRK-Poland relations, I would like to conclude by dividing the conclusion in two parts. The first one is dedicated to the cultural policy of Poland toward the DPRK, and the second one will provide two possible scenarios for how relations might develop between both countries.

5 The quote was issued during an open meeting with students of the University of Warsaw on November $12^{\text {th }}, 2014$ 
Poland may not have a large cultural policy strategy, but looking at the scope and variety of Polish cultural diplomacy and considering how many of the actions are, we cannot but conclude that Poland is doing well and is even ahead of many Western countries in terms of cultural diplomacy toward the DPRK. Most of the Polish cultural diplomacy is government-controlled. This allows Polish authorities to design actions carefully. On the other hand, it hampers the development of a cultural policy based on a network of independent actors. It should be underlined that a deep knowledge of the Other's culture can be the first step towards the improvement of international relations.

Concerning the last point, regarding relations between both countries, we may apply two potential scenarios. The first scenario is the stagnation one: the DPRK continues to pursue provocations and practice a nuclearization policy that will rebuffs Polish efforts to develop a long-term economic cooperation between both countries. In this scenario, the cooperation maybe limited to some kind of cultural exchanges. The second one is the harmonization scenario: after a period of North Korean aggressive policy, the DPRK would withdraw its nuclear capacities. This development may lead to a diplomatic engagement of the DPRK, and cooperation with different partners. The cooperation between the DPRK and Poland may be improved on political, cultural, and economic matters. By discouraging progress on nuclear talks, by withdrawing from International Treaties (such as the Treaty of Non-Proliferation of Nuclear Weapons), the DPRK authorities are discouraging any important progress in their relations with foreign partners such as Poland.

\section{REFERENCES:}

Beck P., Reader N. (2010). Training for Economic Reform. [in:] Europe - North Korea. Between Humanitarianism and Business? M. Park, B. Seliger, S. Park (eds.). Berlin: Lit Verlag.

Bobber A. (2011). The Last Twenty Years of Relations between the Republic of Poland and the Democratic People's Republic of Korea: Selected Aspects (1989-2009). "The Journal of East Asian Affairs" 25, No. 2.

Gertz B. (2005). U.S. Accuses North Korea of \$100 Bill Counterfeiting. “The Washington Times", October 12.

Glaser C. (2010). Rational Theory of International Politics: The Logic of Competition and Cooperation. Princeton: Princeton University Press.

Joon Y. (2010). From Communist Cadres into Capitalistic Managers? The Case of Western 
Business Schools. [in:] Europe - North Korea. Between Humanitarianism and Business? M. Park, B. Seliger, S. Park (eds.). Berlin: Lit Verlag.

KCNA. (2012). Korean Children Prove Successful in International Piano Contest. KCNA, May 18.

Komine Y. (2008). Secrecy in US Foreign Policy: Nixon, Kissinger and the Rapprochement with China. Farnham: Ashgate.

Krysowata J. (2004). Sieroty Koreańskie. „Karta” 42.

Levi N. (2009). Zarys Stosunków między Polska Republika Ludowa a Koreańska Republika Ludowo-Demokratyczna. [in:] Świat i Polska wobec globalnych wyzwań. R. Żelichowski (ed.). Warszawa: Instytut Studiów Politycznych PAN - Collegium Civitas.

Levi N. (2009). North Koreans Suffer Around the World. "DailyNK.com”, June 3.

Levi N. (2010). A Biography of Kim Pyong Il: A Second Dauphin?"Parallax" 1.

Levi N. (2012) Can North Korean Defectors Settle and Live in Central Europe? [at:] Whiter the Two Koreas? Continuity and Change in the North Korean Peninsula, Budapest: Cenral Europe University. September $6^{\text {th }}-8^{\text {th }}$.

Levy J.S. (1997). Prospect Theory, Rational Choice, and International Relations. "International Studies" 41.

Luce R., Raiffa H. (1989). Games and Decisions: Introduction and Critical Survey. Mineola: Dover Publications.

Yang Moonsoo, (2012) North Korea's External Debts: Trend and Characteristics, KDI Review of the North Korea Economy, March.

New Ambassadors Present Credentials. (1998). “Magyar Távirati Iroda”, March 2.

Korea wystrzeliła rakiete. Polski MSZ protestuje, (13 ${ }^{\text {th }}$ December 2012), „Radio Poland".

Park S. (2010). Software and Animation in North Korea. [in:] Europe - North Korea. Between Humanitarianism and Business? M. Park, B. Seliger, S. Park (eds.). Berlin: Lit Verlag.

Roussin S., Ducruet C. (2010). The Nampo-Pyongyang Corridor. [in:] Europe - North Korea. Between Humanitarianism and Business? M. Park, B. Seliger, S. Park (eds.). Berlin: Lit Verlag.

Seliger B. (2010). Capacity Building for Economic Change in North Korea. [in:] Europe - North Korea. Between Humanitarianism and Business? M. Park, B. Seliger, S. Park (eds.). Berlin: Lit Verlag.

Szczudlik-Tatar J., Mejssner P. (2014). Polish-South Korean Relations: New Ways Forward. "Bulletin of the Polish Institute of Foreign Affairs" 55.

Wojnarowski M. (2010). Pan Jo Song-mu i nagroda za promocję Polski w Świecie! „pukhan.pl”, December 19.

Wojniak M. (2006), Korea w Kleczanowie, „Słowo” March 30.

Wystawa koreańskiej sztuki w Gdańsku. (2014). [online] https://kfapolska.wordpress.com/2014/09/17/wystawa-koreanskiej-sztuki-w-gdansku/; [accessed: 19.12.2014]. 
Yang M. (2012). North Korea's External Debts: Trend and Characteristics. "KDI Review of the North Korea Economy".

You Ji (2014). Kim Jong-un's Power Consolidation and Worsening China DPRK Relations. "East Asian Policy" 4.

Joon Young-hur, (2010). From Communist Cadre into Capitalistic Managers?: The Case of Western [in] Myungkyu Park, Bernhard Seliger, Sung-jo Park (eds.), Europe North Korea? Between Humanitarism and Business?, Lit Verlag Berlin. 